\title{
HYBRID URGENT PERCUTANEOUS INTERVENTION IN THE PATIENT WITH FEMORAL ARTERY INJURY AND SHOCK
}

\author{
Ozcem Barcin, Conkbayir Cenk, Akpinar Suha
}

\begin{abstract}
An obese patient with comorbities was admitted to the emergency department with shock, widespread hematoma due to a previous above-knee amputation, and had emergency conventional peripheral angiography in a hybrid operating room after an initial diagnosis of femoral artery fistulisation.

Due to the graft infection, the femoropopliteal graft was removed a month previous. However, bleeding occurred in the native common femoral artery, which had been previously removed and repaired. According to this symptom, coil embolization and gelfoam process were performed as life-saving procedures.
\end{abstract}

Russ J Cardiol 2014, 1 (105), Engl.: 52-53

Key words: femoral artery injury, coil embolization, percutaneous transcatheter embolization.
Department of Cardiovascular Surgery, Department of Cardiology, Department of Radiology, Faculty of Medicine, Near East University, Nicosia, Cyprus.

Corresponding author. Barçın Özcem MD, Department of Cardiovascular Surgery, Faculty of Medicine, Near East University, Nicosia, North Cyprus, Tel: +903926751000/2005, e-mail: drbarcinozcem@gmail.com

Received September 24, 2013.

Revision received October 16, 2013.

Accepted October 23, 2013.

\section{СРОЧНОЕ СМЕШАННОЕ ЧРЕСКОЖНОЕ ВМЕШАТЕЛЬСТВО ЧЕРЕЗ БЕДРЕННУЮ АРТЕРИЮ ПАЦИЕНТА С ТРАВМОЙ И ШОКОМ}

\author{
Ozcem Barcin, Conkbayir Cenk, Akpinar Suha
}

Пациент с ожирением и сопутствующими заболеваниями был госпитализирован в отделение неотложной помощи с шоком, обширной гематомой, из-за предыдущей ампутации выше колена; ему проведена экстренная периферическая ангиография в условиях смешанной экстренной операционной после первичного диагноза фистулы бедренной артерии.

Из-за инфекции феморопоплитеальный графт был удален месяцем ранее. Однако, произошло кровотечение из общей бедренной артерии, которое было

\section{Introduction}

Surgical interventions and vascular repair are performed widely worldwide in arterial injuries. Today, interventional intravascular procedures may be applied alone or in combination with surgery in hybrid operating rooms both for reducing operative risks, mortality and morbidity in patients who have comorbid risk factors.

In this paper, we wanted to discuss urgent percutaneous intervention in a patient for whom surgery was a high risk.

\section{Case report}

A seventy year old male patient was admitted to the emergency department with shock (blood pressure 60/40 mmhg). Upon physical examination, it was noted that he had an amputation above the knee in the left lower extremity, severe tension, hematome in stump site, and even leakage in suture line. His body temperature was $37.8^{\circ}$, and WBC and CRP were elevated. It was learned that he had undergone revascularization many times for the same limb, and his last intervention was a femoropopliteal bypass operation with graft. This patient had a couple of bypass interventions which were occluded and infected. Because of infection, the graft was removed, and the patient had an above the knee amputation. The patient had dehiscence of sutures in the femoral artery, leading to a large hematoma and shock. ранее остановлено. В соответствии с этим, эмболизация и применение гельфоума были выполнены в качестве жизнесохраняющей процедуры.

Российский кардиологический журнал 2014, 1 (105), Англ.: 52-53

Ключевые слова: травма бедренной артерии, эмболы, чрескожная транскатетерная эмболизация.

The infected graft was removed after revascularization was done one month previous. Common femoral artery, proximal part of the graft was repaired, and an above-knee amputation was performed in the same session. Severe scar tissue was detected in his left inguinal region due to multiple operations. Ultrasonography revealed a widespread subcutaneous hematoma. The patient, who had many comorbidities, was immediately taken to the hybrid operating room. 5F sheath was inserted from the contralateral limb under local anaesthesia, turned to left common iliac artery from aortic bifurcation, and selective right femoral angiography was performed. On vascular imaging, contrast medium passage was observed to come out from above the potential native vessel (common femoral artery) of the femoropopliteal graft, which was reported to have been removed in the previous operation (Fig. 1). We immediately applied embolization with two $4 \mathrm{~mm} / 40 \mathrm{~mm}$ and one 5 $\mathrm{mm} / 50 \mathrm{~mm}$ of Boston scientific brand fiber coil. We saw that extravasation decreased but continued, so we performed balloon dilatation to the proximal part of the coil site, and that enabled the stop of flow and, thereby, embolization of the leakage site with gelfoam (Fig. 2). We detected that the complication was a partial stenosis in this artery due to the gelfoam going to the superficial femoral artery. Fistulisation was successfully stopped. 


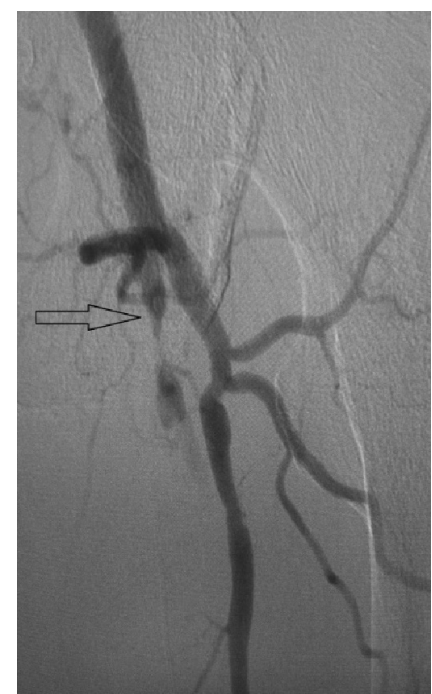

Figure 1. Contrast passage is seen in common femoral artery

Boston Scientific brand of stent, $4.5 \mathrm{~mm}$ in diameter, was implanted to this stenosis, and the procedure was terminated successfully (Fig. 3).

\section{Discussion}

Percutaneous transcatheter embolization is quite safe and has good results in certain lower extremity arterial injuries, particularly in patients with many comorbidities. The general approach in arterial injuries leading to extreme ischemia is urgent exploration and vascular repair. However, general anaesthesia, blood loss, infection, wound aperture and lymphorrhea are the risks of surgery. Exploration is quite difficult morbidly obese patients and in a surgical field which has scarring due to previous operations [1]. Percutaneous transcatheter arterial embolization is a good option for reducing surgical risks or when used in combination with surgery. PTE applications require experience and may be applied by interventional radiologists or vascular surgeons with a multidisciplinary approach [2]. In their study of 10 cases, Aksoy et al. used coil and gelfoam to stop haemorrhage in percutaneous approaches to lower extremity vascular injuries. They obtained successful results in all patients; they reported quite low rates of duration of hospital stay and complications [3]. Further developments in guidewires will enable safer PTE with less risk $[4,5]$.

On the other hand, if there is infection in the site of percutaneous embolization, intravenous antibiotics should

\section{References}

1. Panetta T, Sclafani SJ, Goldstein AS, et al. Percutaneous transcatheter embolization for arterial Trauma. J Vasc Surg 1985;2: 54-64.

2. Naidoo NM, Corr PD, Robbs JV, et al. Angiographic embolisation in arterial trauma. Eur J Vasc Endovasc Surg 2000;19: 77-81.

3. Aksoy M, Taviloglu K, Yanar H, et al. Percutaneous Transcatheter Embolization in Arterial Injuries of the Lower Limbs Acta Radiol 200546: 471.

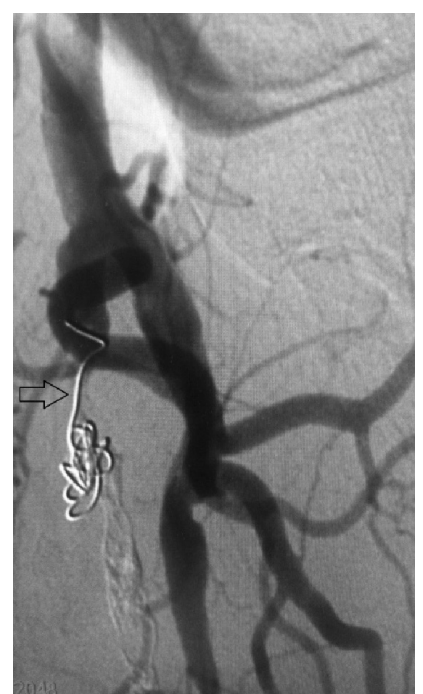

Figure 2. Passage is seen to be eliminated following coil and gelfoam application to the fistula in common femoral artery.

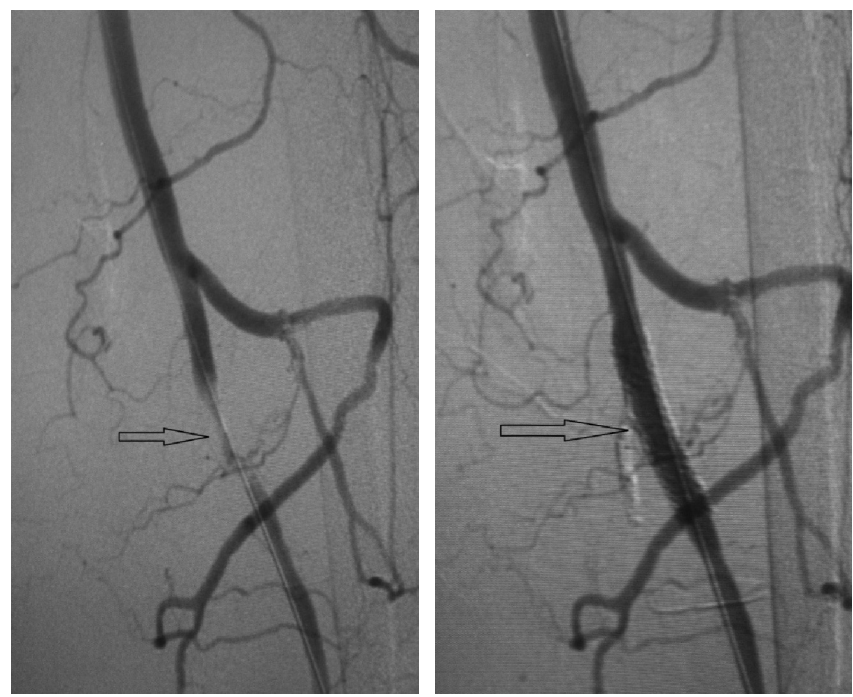

Figure 3. Stenosis in superficial artery developed due to gelfoam is seen on the left. Elimination of this stenosis with a $4.5 \mathrm{~mm}$ stent is seen on the right.

be given before the procedure. Our patient recovered well from infection without fever, and CRP and WBC decreased. If the patient is in shock, PTE can be performed safely as in our case if there is infection, also.

In conclusion, although PTE requires a multidisciplinary approach, it can be performed safely in experienced hands to reduce surgical risks, particularly, in patients with multiple comorbidities. 